\title{
The Myth of Eating Every Three Hours
}

\author{
Ed Wilson Santos* \\ Department of Clinical Toxicological Analyses, Faculty of Pharmaceutical Sciences, University of Sao Paulo, Brazil
}

Submission: December 21, 2017; Published: February 01, 2018

*Corresponding author: Ed Wilson Santos, Experimental Hematology Laboratory, Department of Clinical Toxicological Analyses, Faculty of Pharmaceutical Sciences, University of Sao Paulo, Brazil, Email: ed.wilson@usp.br

\section{Opinion}

Most dietitians and enthusiasts of physical culture preach that the habit of eating every three hours is highly beneficial to the body and it aids in weight loss. And not only that, the benefits cited range from speeding up metabolism to controlling the glycemic rate and decreasing the risks of diabetes.

However, there is no scientific proof of these benefits. Quite the contrary, a study by the University of Nottingham pointed to an increase in the metabolic rate after prolonged fasting in both men and women [1]. Another obese study, conducted by the University of Ottawa in Canada, concluded that fractionating meals does not promote weight loss [2].

French researchers have published in the British Journal of Nutrition, an epidemiological study evaluating several publications of the last decades that speak on the subject and concluded that there is no evidence that the consumption of fractional meals brings such benefits [3].

A study by the University of California evaluated subjects undergoing food restriction for three days and also found no significant differences in metabolic rate [4]. It is clear that eating does not accelerate the metabolism as many expected.

Most of the people who spread this myth are only passing on information they have heard, not even knowing that it has already been considered false for almost 20 years. In the last century it was believed that eating less often is more beneficial to the body [5]. No study published in recent decades has shown that feeding every three hours helps metabolism.

A study published by the prestigious American Journal of Clinical Nutrition evaluated men and women who had fasting every other day. For 22 days they fed normally and the other day they went through fasting. The results put down the myth of eating to accelerate metabolism, as the resting metabolic rate did not change significantly throughout the study, not even on the days of fasting. Even body temperature did not change in the individuals studied [6].

The principle of eating to accelerate the metabolism is based on the premise that the ingestion of food promotes the thermal effect. This really happens. However, the acceleration of metabolism is proportional to the amount of calories consumed. Eating only a bar of cereal or a fruit will promote an insignificant metabolism increase [7].

A Dutch group evaluated volunteers who ate two meals a week, and then the same individuals ate seven meals a day for another week. There was no significant difference in the metabolic rate of individuals [8].

Similarly, a study in Prague evaluated two groups of people, one who ate twice a day and one who ate six meals a day. The amount of calories of the two groups being the same. The result was surprising. The group that consumed two meals had an increase in weight loss and an improvement in insulin production [9].

Although some people report that eating every 3 hours reduces hunger in large meals and improves satiety, many people report that their binge eating has increased and the effects on the balance have been reversed. Eating more often can make you lose track of how much you are consuming, leading to weight gain.

In fact, it's not the frequency that matters but what you eat. If you have ever eaten a bakery you will remember that you have spent little time getting hungry again because carbohydrates increase the glycemic rate quickly and then fall, giving you the feeling of hunger. Increased protein intake helps control appetite and weight gain [10].

Food is a fundamental part of good health. Select well what you will eat and when you will do it to have a healthy life.

\section{References}

1. Webber J, Macdonald IA (1994) The cardiovascular, metabolic and hormonal changes accompanying acute starvation in men and women. Br J Nutr 71(3): 437-447.

2. Cameron JD, Cyr MJ, Doucet E (2010) Increased meal frequency does not promote greater weight loss in subjects who were prescribed an 8-week equi-energetic energy-restricted diet. Br J Nutr 103(8): 10981101. 
3. Bellisle F, McDevitt R, Prentice AM (1997) Meal frequency and energy balance. Br J Nutr 77(Suppl 1): S57-S70.

4. Keim NL, Horn WF (2004) Restrained eating behavior and the metabolic response to dietary energy restriction in women. Obes Res 12(1): 141-149.

5. White EG (1965) Conselhos Sobre Regime Alimentar. Casa Publicadora Brasileira, São Paulo, Brazil.

6. Heilbronn LK, Smith SR, Martin CK, Anton SD, Ravussin E (2005) Alternate-day fasting in nonobese subjects: effects on body weight, body composition, and energy metabolism. Am J Clin Nutr 81(1): 6973.

7. Crovetti R, Porrini M, Santangelo A, Testolin G (1998) The influence of thermic effect of food on satiety. Eur J Clin Nutr 52(7): 482-488.
8. Verboeket-van de Venne WP, Westerterp KR, Kester AD (1993) Effect of the pattern of food intake on human energy metabolism. Br J Nutr 70(1): 103-115.

9. Kahleova H, Belinova L, Malinska H, Oliyarnyk O, Trnovska J, et al. (2014) Eating two larger meals a day (breakfast and lunch) is more effective than six smaller meals in a reduced-energy regimen for patients with type 2 diabetes: a randomized crossover study. Diabetologia 57(8): $1552-1560$

10. Leidy HJ, Armstrong CL, Tang M, Mattes RD, Campbell WW (2010) The influence of higher protein intake and greater eating frequency on appetite control in overweight and obese men. Obesity (Silver Spring) 18(9): 1725-1732.

\section{Your next submission with Juniper Publishers will reach you the below assets}

- Quality Editorial service

- Swift Peer Review

- Reprints availability

- E-prints Service

- Manuscript Podcast for convenient understanding

- Global attainment for your research

- Manuscript accessibility in different formats ( Pdf, E-pub, Full Text, Audio)

- Unceasing customer service

Track the below URL for one-step submission https://juniperpublishers.com/online-submission.php 